\title{
Premium potential for geographically labeled, differentiated meat products
}

\author{
Kynda R. Curtis ${ }^{a}$ \\ Utah State University
}

Submitted September 6, 2013 / Revised November 26, 2013, and January 13, 2014 / Accepted January 14, 2014 /

Published online March 19, 2014

Citation: Curtis, K. (2014). Premium potential for geographically labeled, differentiated meat

products. Journal of Agriculture, Food Systems, and Community Development, 4(2), 97-111.

http://dx.doi.org/10.5304/jafscd.2014.042.016

Copyright (C) 2014 by New Leaf Associates, Inc.

\begin{abstract}
Growing consumer demand for local foods and products grown under specialty production systems provides livestock producers with the opportunity to increase profits and reduce variability through production of high-value finished meat products, integration of additional species, and targeted marketing efforts. This study examines consumer preferences and willingness to purchase and pay premiums for origin-labeled differentiated beef, pork, and lamb products through a mail survey of Nevada residents. Logit model results show important differences in consumer preferences across meat products. Pricing premiums for differentiated pork and lamb products ranged from 11 to 15 percent, while those for beef products ranged from 22 to 40 percent. Additionally, premiums were higher for superior meat cuts. Product appearance attributes such as marbling, texture, and brand had a significant impact on consumer willingness to pay for all products, while product credence attributes, such as production
\end{abstract}

a Associate Professor, Department of Applied Economics, 4835 Old Main Hill, Utah State University, Logan, Utah 84322 USA; +1-435-797-0444; kynda.curtis@usu.edu method and origin, only had a significant impact on consumer willingness to pay for commonly known beef products. Target consumers for local differentiated pork and lamb products include higher-income, white married adults with children. Target consumers for beef products include higher-income, younger white adults. Study results show the importance of targeted consumer marketing for less commonly consumed products, such as lamb. Including information on the health benefits of specialized production methods in marketing materials would also be useful, especially if targeting seniors and ethnic groups.

\section{Keywords}

cheap talk, consumer willingness to pay (WTP), differentiated meats, natural, origin labeling, statesponsored designations (SSDs)

\section{Introduction}

Significant price volatility and economic losses in the livestock industry combined with increased consumer demand for differentiated meat products have led producers to consider alternative management strategies (see figure 1). These strategies include shifting from traditional cow-calf opera- 
tions to production and direct sales of differentiated, highvalue finished meat products and the incorporation of additional species into current livestock operations. The feasibility of such strategies has been enhanced by increased consumer interest and willingness to pay (WTP) premiums for meat products labeled with credence ${ }^{1}$ attribute information, such as origin and special production techniques. The prevalence of branding and labeling programs based on the geographic area of production (such as region, state, or country), and on production techniques (such as organic, natural, and grass-fed) has simplified access to markets and adoption of alternative management strategies among livestock producers.

Although differentiated products may capture premiums, they also present additional production costs, as well as slaughter, processing, and marketing issues for livestock producers (Acevedo, Lawrence, \& Smith, 2006). Origin labels ease consumer concerns regarding food safety and the environmental impacts of food production and transportation, and also appeal to the increasing consumer demand for locally produced foods (Burnett, Kuethe, \& Price, 2011; Curtis \& Cowee, 2011; Curtis, Cowee, Velcherean \& Gatzke, 2010). Additionally, forage-based livestock feeding programs have been shown to have many health benefits for consumers (Duckett, Wagner, Yates, Dolezal, \& May, 1993) as well as environmental and resource sustainability benefits to society. For example, Pimentel, Oltenacu, Nesheim, Krummel, Allen, and Chick (1980) found that grass feeding reduces livestock production energy needs by 60 percent and land resources by 8 percent. Hence the combination of local origin and natural grass-fed

${ }^{1}$ Credence attributes are those that cannot be ascertained though product visual inspection or consumption. production methods may provide price premiums sufficient to cover the additional production and marketing costs observed by livestock producers.

The purpose of this study is to evaluate market and pricing potential for multiple state origin-labeled differentiated meat products through a mail survey of Nevada residents. We seek to determine the effect of consumer sociodemographics, meat purchasing habits, meat attributes, and cheap talk and auction scripts ${ }^{2}$ on consumer willingness to purchase local differentiated meat products and their willingness to pay (WTP) premiums for such products. The data were collected through a mail survey of 542 households across the state of Nevada. Logit models were used to examine consumer willingness to purchase and pay for NevadaGrown grass-fed beef and lamb, and natural pork products. While the results are specific to the western United States, the conclusions are likely of interest to livestock producers and meat marketers

\footnotetext{
${ }^{2}$ Cheap talk and auction scripts are used to correct for consumer bias in stated preference surveys. Survey respondents are provided information on the meaning and underpinnings of hypothetical bias and asked to consider their true willingness to pay and budget in their decision. The auction script describes how the auction process encourages consumers to bid their true willingness to pay.
} 
generally, especially those looking to understand the market potential for less commonly consumed, differentiated local pork and lamb products.

\section{Previous Literature}

A significant amount of interest in food products labeled for geographic location of production has emerged in the literature. Differentiating food products by geographic area of production is especially important in Europe, where the European Union (EU) has granted legal protection to these products through the EU Protected Geographical Indication (PGI). Research shows that PGIs are recognized by consumers and are capable of adding value to food products (McCluskey \& Loureiro, 2003; Resano, Sanjuan, \& Albisu, 2009). The reputation and promotion of PGIs are built principally on consumers' perceived quality of these products.

In the United Sates we see a proliferation in geographic labeling programs in the form of statesponsored designations, or SSDs. SSDs have been common since the 1980s, but the "buy-local" movement has increased interest in the use of SSDs to address consumer interested in purchasing "local" food items. As a consequence, state-based promotional programs have seen a rapid proliferation since 2001 (Onken \& Bernard, 2010). The effectiveness of state labeling programs in increasing consumer WTP for food products is noted in several studies. Examples include a study by Nganje, Hughner, and Lee (2011), who examined Arizona Grown carrots and spinach, and a study by Bailey, Bosworth, and Curtis (2012) examining Utah's Own labeled ice cream products.

In recent years, numerous studies have sought to determine consumer WTP for beef products with origin and production protocol labels, such as steak and ground beef. Examples examining the impact of geographic regions of production and/or origin include a study by Umberger, Fuez, Calkins, and Sitz (2003) which estimated consumer WTP by country of origin labeling (COOL) for steak and hamburger, as well as for steak with a guarantee of U.S. production, and steak with both the U.S. guarantee and a regional label. Consumers were willing to pay premiums of 11 to 24 percent depending on the cut of meat and label, and respondents who were presented with the regional label were 15 percent more likely to pay a premium for the guaranteed U.S. product. Louriero and Umberger (2003) found that respondents were willing to pay premiums of 38 percent and 58 percent for steak and hamburger with a "Certified U.S." label. Loureiro and Umberger (2005) estimated consumer premiums of 2.9 percent, 2.5 percent, and 2.5 percent for U.S.-certified ribeye steak, chicken breasts, and pork chops, respectively.

Umberger, Feuz, Calkins, and Killinger-Mann (2002) used an experimental auction to assess consumer WTP for domestic corn-fed beef and Argentine grass-fed beef based on product flavor characteristics. While 23 percent of respondents were willing to pay a premium for the grass-fed beef, 62 percent were willing to pay a premium for the corn-fed beef (the remaining 15 percent were indifferent between the two). The authors contend that there are two specific consumer groups, one preferring grain-fed and the other grass-fed, and that each is willing to pay a significant premium for their preference. Feuz, Umberger, Calkins, and Sitz (2004) came to a similar conclusion in their estimation of consumer WTP for quality attributes of beef steak, including flavor and country of origin. They found that respondents were able to taste a difference in flavor between domestic corn-fed beef, Australian grass-fed, and Canadian barley-fed beef even in a blind taste test.

Mennecke, Townsend, Hayes, and Lonergan (2007) used conjoint analysis to determine the features of an "ideal" steak. They found that region of origin was the dominant characteristic in the steak-purchasing decision, while feed type was less important. In general, respondents preferred the grain-fed over the grass-fed steak. Abidoye, Bulut, Lawrence, Mennecke, and Townsend (2011) found that the characteristics of traceability, grass-fed, and U.S. origin were highly valued by U.S. consumers, who were willing to pay an average price premium of about 34 percent for grass-fed assurance in beef steak. Evans, D'Souza, Collins, Brown, and Sperow (2011) found that through the use of experimental auction techniques, consumers in Pennsylvania and West Virginia were more likely to prefer grass-fed Appalachian beef over grain-fed 
samples due largely to nutritional content and other observed product attributes.

Additional literature examines consumer preferences and willingness to pay premiums for grass-fed beef products as a result of consumer health perceptions. A study by Lusk and Parker (2009) found that consumers preferred grass-fed beef over supplementing a primarily grain diet to improve Omega 6:3 ratios, and a study by Umberger, Boxall, and Lacy (2009) showed that health-related messages and nutritional-content labeling were important drivers of U.S. consumer W'TP for grass-finished beef. Xue, Mainville, You, and Nayga (2010) and Chang, Xu, Warmann, Lone, Munzimi, and Opoku (2013) found that in addition to consumer beef consumption rates, experience with food-related diseases and nutrient and health knowledge significantly impact consumer WTP for local and grass-fed beef.

Lusk, Fields, and Prevatt (2008) estimated consumer WTP for beef products (ribeye steak and ground beef) that varied by feed type, antibiotic use, traceability, package size, and price; they found that although consumers preferred pasture-fed beef to a product with no feed information and traceability, consumers were more concerned with antibiotic use than either feed type or traceability. McCluskey, Wahl, Li, and Wandschneider (2005) estimated consumer WTP for grass-fed beef from a health benefits standpoint. Results of a choicebased conjoint analysis showed that consumers were willing to pay a premium of US $\$ 5.65$ per pound for a low-fat, low-calorie beef steak (the grass-fed steak) relative to a high-fat, high-calorie steak (the conventional steak), and that a steak containing high levels of omega-3s could earn a premium of US $\$ 3.42$ per pound over a standard steak. However, the authors state that these premiums may be high as nearly half the respondents were surveyed in a natural foods store. This is confirmed by Conner and Oppenheim (2008), who found that consumer WTP for pasture-raised beef and milk was higher among natural food store customers than traditional grocery store customers.

Few studies examine consumer preferences for alternative production protocols for non-beef products such as lamb, pork, or poultry. One example includes a study by Grannis and Thilmany
(2000) based on a 1998 mail survey of U.S. residents concerning consumer WTP for natural meats, including natural pork products. Results show that 29.7 percent were willing to pay a 10 percent price premium for natural pork chops and 6.25 percent were willing to pay a 20 percent price premium. At a 10 percent premium, 40 percent were willing to buy natural ham, and at a 20 percent price premium, 14.2 percent were willing to buy natural ham.

This study builds on past findings by incorporating a production protocol with a state designated origin label (NevadaGrown) in a nonseparable manner in order to examine consumer WTP for multiple differentiated meat products (by type and cut), including beef, lamb, and pork. Additionally, consumer demographics, preferences for meat attributes, and meat purchase outlet are examined for their potential impact on consumer WTP and purchase local differentiated meat products.

\section{Data and Methods}

The data were collected though a mail survey (2007-2008) sent to a random sampling of 5,200 households across Nevada, with 542 surveys returned and considered viable for a response rate of 10.4 percent. A modified Dillman (2000) approach was used to conduct the survey, in that the initial survey mailing was followed by reminder postcards mailed in the second and fourth weeks afterward. A cover letter accompanying the survey discussed the research objectives as well as the potential benefits to consumers and livestock producers. The survey sample demographics were representative of the state of Nevada (U.S. Census Bureau, n.d.), with median annual income of US $\$ 45,000$ to US $\$ 60,000$, median age of 46 to 55 years, 56 percent female, and a median education attainment level of "some college." Approximately one-third had children in the household (31 percent), 63 percent were married, and 81 percent identified themselves as White (higher than the Nevada population at 66 percent). The respondents were largely from southern Nevada (58 percent). A large portion of the households were small, with 63 percent reporting 1-2 members and 27 percent reporting 3-4 members. About two- 
thirds of the sample was employed full-time (59 percent), while 25 percent were retired.

The respondents were asked to rate 18 separate meat attributes in terms of importance in their meat purchasing decisions on a rating scale of one to five, where one indicated the attribute was not important and five indicated the attribute was extremely important. Meat freshness, taste/flavor, safety, and tenderness were assigned the highest average ratings over the sample (see table 1). Animal feed type (such as grain or grass-fed) and product origin were ranked in the bottom third, with brand name ranked as the least important attribute. To assess the effect of meat purchasing outlets on preferences and WTP, respondents were asked where primarily they purchase their meats. Traditional grocery stores were most often reported, followed by warehouse stores (such as Costco), specialty meat stores, natural food stores, making purchases directly from a farm, and making purchases over the Internet.

One potential issue in stated preference studies is that respondents often overestimate their WTP or purchase goods and services, viewing the survey questions as hypothetical, which results in survey bias. In an effort to control hypothetical bias, four survey treatments were used, including one using a "cheap talk" script, which advises respondents of the potential for hypothetical bias and asks that they consider their true preferences and budgetary constraints. A basic cheap talk script has been shown to greatly reduce differences between hypothetical and non-hypothetical W'TP estimates (Silva, Nayga, Campbell \& Park, 2011). The second treatment included an auction script that explained how auctions work and how they encourage participants to bid their true WTP. The third treatment incorporated both the cheap talk and auction scripts, and the final treatment, a control treatment, provided no script or additional information.

To minimize reference point effects, a doublebounded contingent valuation and payment card hybrid design was used, similar to that of $\mathrm{Hu}$ (2006) and Hu, Zhong, and Ding (2006). Each respondent was asked to complete two payment cards, such as one card for the New York steak (often called strip steak) cut and a second card for

Table 1: Attribute Ratings and Factor Analysis Results (ratings on a 1-5 scale)

\begin{tabular}{|c|c|c|c|c|c|}
\hline \multirow[b]{2}{*}{ Attribute } & \multirow{2}{*}{$\begin{array}{l}\text { Mean Attribute } \\
\text { Rating }\end{array}$} & \multicolumn{4}{|c|}{ FactorName } \\
\hline & & CREDENCE & EXPERIENCE & APPEARANCE & MARKETING \\
\hline Naturally raised/produced & 3.56 & 0.894 & & & \\
\hline $\begin{array}{l}\text { Produced following environmentally } \\
\text { friendly practices }\end{array}$ & 3.64 & 0.870 & & & \\
\hline Organic & 3.46 & 0.804 & & & \\
\hline $\begin{array}{l}\text { Certified as following humane animal } \\
\text { treatment standards }\end{array}$ & 3.76 & 0.737 & & & \\
\hline Feed type & 3.52 & 0.730 & & & \\
\hline Origin & 3.03 & 0.666 & & & \\
\hline Taste and flavor & 4.69 & & 0.901 & & \\
\hline Freshness & 4.70 & & 0.885 & & \\
\hline Tenderness & 4.42 & & 0.759 & & \\
\hline Safety assurances & 4.53 & & 0.694 & & \\
\hline Leanness & 4.20 & & 0.624 & & \\
\hline Marbling & 3.62 & & & 0.737 & \\
\hline Muscle texture & 3.55 & & & 0.729 & \\
\hline Sold under familiar brand name & 2.79 & & & 0.530 & \\
\hline Cut type & 3.91 & & & 0.509 & \\
\hline Sold under sale or promotion & 3.29 & & & & 0.837 \\
\hline Price & 4.14 & & & & 0.646 \\
\hline Packaging & 3.53 & & & & 0.561 \\
\hline
\end{tabular}


the leg of lamb cut. Each payment card gave the respondent the opportunity to choose between the conventionally produced cut (Product A) and the NevadaGrown grass-fed/natural cut (Product B). If the respondent chose Product B (NevadaGrown grass-fed/natural), he or she was presented with four new prices increasing in US $\$ 0.25$ increments from the original price offered and given the option to write in the highest price they would be willing to pay. If the respondents initially choose Product A (conventionally produced), they were asked to choose the highest price they would be willing to pay for Product B from a list of four prices in amounts decreasing from the original price offered in US $\$ 0.25$ increments, with the option to write in the highest price they would be willing to pay.

The Product A prices represented the current local price for the meat type and cut under consideration. The Product B prices were drawn from a series of prices that were considered to be much lower, slightly lower, slightly higher, or much higher than the local average at the time of the study. Eight different combinations of prices were used. In total, there were 128 versions of the survey representing all possible combinations of meat cuts, information treatments, and pricing schedules, so that the survey design was fully orthogonal over the entire sample.

\section{Model Estimation}

Survey responses were analyzed following Lancaster's (1966) approach to consumer demand, which posits that when presented with product options, consumers will choose the product whose characteristics maximize their utility. Lancaster's theory states that that utility derived from consumption of a product is a function of the attributes of the product,

$$
U_{i j}=U_{i j}\left(z_{1}, z_{2}, \ldots, z_{m}\right)
$$

where $z_{i}=a_{i j} q_{j}$ is the amount of the $i$ th attribute achieved from consumption of the $j$ th product, $a_{i j}$ is the amount of the $i$ th attribute per unit of the $j$ th product, $q_{j}$ is the quantity of the $j$ th good consumed, and $U_{i j}$ is the corresponding utility level derived through that consumption (Gracia \& de Magistris, 2008). Consumers are then assumed to choose the product with the attribute mix that maximizes their utility. In this case, consumers were presented with two products, the differentiated (NevadaGrown grass-fed/natural) meat product (Product B) and the conventionally produced product (Product A). The probability of a consumer choosing the differentiated product is dependent on the probability that the utility derived from consumption of the differentiated product is greater than the utility derived from consumption of the conventional product,

$$
P\left(y_{d}\right)=P\left(U_{i d}>U_{i c}\right) \text {. }
$$

Two logit models were estimated using respondent socio-demographic data, meat purchasing habits, and four variables related to preferences for meat attributes obtained through factor analysis of the original 18 attributes. In the first model, the dependent variable was willingness to purchase the differentiated meat products (with a value of 1 if the respondent was willing to purchase the NevadaGrown grass-fed product, 0 otherwise), while the second model included the same independent variables with willingness to pay a premium as the dependent variable (with a value of 1 if the respondent was willing to pay a premium for the differentiated meat, 0 otherwise). The models were estimated as

$$
\mathbf{y}=\mathbf{x}^{\prime} \boldsymbol{\beta}+\mathcal{\varepsilon} \text { where } \mathcal{E} \sim \mathrm{N}[0,1],
$$

such that the probability of a "yes" response (i.e., willing to purchase or willing to pay a premium) is

$$
\operatorname{Prob}(Y=1 \mid \mathbf{x})=\frac{e^{\mathbf{x}^{\prime} \mathbf{\beta}}}{1+e^{\mathbf{x}^{\prime} \mathbf{\beta}}} .
$$

Consumer WTP for each meat type was estimated with WTP for the differentiated meat as the dependent variable and the highest price the respondent was willing to pay as the independent variable, such that

$$
\mathrm{WTP}=\alpha-\rho \cdot x_{i},
$$

where $a$ is the slope of the function (the coefficient on the constant) and $\varrho$ is the coefficient on the bid. Following this, mean WTP was calculated as

$$
\overline{\mathrm{WTP}}=\frac{-\alpha}{\rho} .
$$


The logit analysis incorporated four factors obtained through factor analysis performed on the 18 meat attributes that respondents rated in terms of perceived importance in their meat purchasing decisions. Principal components factor analysis with varimax rotation and Kaiser normalization was used to extract the four factors. Factor loadings and the attributes embodied by each factor are summarized in table 2 .

The first factor contained the statements pertaining to natural production, environmentally friendly production, organic production, certified humane production, livestock feed type, and geographical origin of the meat. As these components are all related to production protocols, and are all considered credence attributes, this factor was given the name "CREDENCE." The second factor contained the attributes of taste and flavor, freshness, tenderness, safety assurances, and leanness. As these attributes are all considered experience attributes (elements of a product that can only be detected through consumption), this factor was called "EXPERIENCE." The third factor contained the attributes of marbling of meat, muscle texture, brand name, and cut type, so the factor was given the name "APPEARANCE," as these attributes can all be considered appearance attributes (attributes that can be noted from inspection of the product). The final factor contained two cost attributes (the importance of meat being sold under a sale or promotion and the price of meat) as well as the meat product's packaging and was termed "MARKETING," as these components all relate to marketing techniques.

In addition to the four factors, we included variables "NATURALSTORES," a measure of how often the respondent purchases meat at natural food stores, and "SPECIALTYMEAT," a measure of how often the respondent purchases meat at specialty meat stores (such as butcher shops). Demographic variables included "FEMALE," "EDUCATION," "INCOME," "MARRIED," "KIDS" (children 18 and under in household), "AGE," "WHITE," and "HHSIZE" (household size). Finally, "CHEAPTALK," "AUCTION," and "BOTH" were included to examine the effects of these scripts on respondent
WTP. All model variables are summarized in table 2 , and the final model was estimated as

$$
\begin{array}{ll} 
& \mathbf{y}_{d}=\beta_{0}+\beta_{1} \text { CREDENCE }+\beta_{2} \text { EXPERIENCE }+\beta_{3} \text { APPEARANCE } \\
& +\beta_{4} \text { MARKETING }+\beta_{5} \text { NATURALSTORES }+\beta_{6} \text { SPECIALTYMEAT } \\
(7) & +\beta_{7} \text { FEMALE }+\beta_{8} \text { EDUCATION }+\beta_{9} \text { INCOME }+\beta_{10} \text { MARRIED } \\
& +\beta_{11} \text { KIDS }+\beta_{12} \text { AGE }+\beta_{13} W H I T E+\beta_{14} \text { HHSIZE }+\beta_{15} \text { CHEAPTALK } \\
& +\beta_{16} \text { AUCTION }+\beta_{17} \text { BOTH }+\varepsilon
\end{array}
$$

where $\mathbf{y}_{d}$ is the probability of a consumer's willingness to purchase the differentiated meat product (Product B) in the first analysis $(d=1)$, and consumer WTP a premium for the differentiated meat product (Product B) in the second analysis $(d=2)$. The two-model analysis was conducted to provide more detailed information on those consumers' WTP premiums for the Product B option meat products.

\section{Model Results}

The results of the two logit models are provided in the appendix: table A1 (willingness to purchase Product $\mathrm{B}$ ) and table A2 (willingness to pay a premium for Product B). The results show differences in willingness to purchase and WTP a premium between the beef, lamb, and pork products. "CREDENCE," the factor related to differentiated meat production attributes, including both feed type and point of origin, had positive and significant effects on willingness to purchase and WTP a premium for the differentiated steak and ground beef products (12.2 percent and 8.5 percent for steak, 17.7 percent and 7.2 percent for ground beef), but did not have an effect on willingness to purchase or WTP a premium for either leg of lamb or pork chops. This is perhaps due to the prevalence of grass-fed and originlabeled beef products, which are increasingly common in conventional grocery outlets, while similarly produced lamb and pork products are not yet so visible.

Meat "APPEARANCE" attributes had a positive and significant effect on consumer willingness to purchase across all meat types and ranged in effect from increasing the probability of willingness to purchase by 6.5 percent for steak to 8.9 percent for leg of lamb. It was also positive and significant in the WTP a premium stage for New York steak and pork chops at 6.1 percent and 7.9 percent, respectively, indicating that despite the 
Table 2. Model Variable Descriptions and Statistics

\begin{tabular}{|c|c|c|c|}
\hline Variable & Description & Mean & Std. Dev. \\
\hline Steak & 1 if willing to purchase differentiated steak product; 0 otherwise & 0.61 & 0.48 \\
\hline Ground Beef & 1 if willing to purchase differentiated ground beef product; 0 otherwise & 0.61 & 0.49 \\
\hline Pork Chops & 1 if willing to purchase differentiated pork product; 0 otherwise & 0.56 & 0.49 \\
\hline Leg of Lamb & 1 if willing to purchase differentiated lamb product; 0 otherwise & 0.45 & 0.49 \\
\hline \multirow[t]{3}{*}{ NATURALSTORES } & 1: Never purchase meat at natural food stores & 2.1 & 0.55 \\
\hline & 2: Sometimes purchase meat at natural food stores & & \\
\hline & 3: Frequently purchase meat natural food stores & & \\
\hline \multirow[t]{3}{*}{ SPECIALTYMEAT } & 1: Never purchase meat at specialty meat stores & 2.25 & 0.55 \\
\hline & 2: Sometimes purchase meat at specialty meat stores & & \\
\hline & 3: Frequently purchase meat at specialty meat stores & & \\
\hline FEMALE & 1 if female; 0 otherwise & 0.56 & 0.5 \\
\hline \multirow[t]{6}{*}{ EDUCATION } & 1: Completed middle school & 3.96 & 1.34 \\
\hline & 2: Completed high school & & \\
\hline & 3: Some college & & \\
\hline & 4: 2-year degree & & \\
\hline & 5: 4-year degree & & \\
\hline & 6: graduate degree or higher & & \\
\hline \multirow[t]{6}{*}{ INCOME } & 1: less than $\$ 30,000$ & 3.64 & 1.67 \\
\hline & $2: \$ 30,000-\$ 45,000$ & & \\
\hline & 3: $\$ 45,000-\$ 60,000$ & & \\
\hline & 4: $\$ 60,000-\$ 75,000$ & & \\
\hline & 5: $\$ 75,000-\$ 100,000$ & & \\
\hline & 6: more than $\$ 100,000$ & & \\
\hline MARRIED & 1 if married; 0 otherwise & 0.63 & 0.48 \\
\hline KIDS & 1 if children under 18 in household; 0 otherwise & 0.31 & 0.46 \\
\hline \multirow[t]{7}{*}{ AGE } & 1: $18-25$ years & 4.16 & 1.37 \\
\hline & 2: $26-35$ years of age & & \\
\hline & 3: $36-45$ years of age & & \\
\hline & 4: $46-55$ years of age & & \\
\hline & 5: $56-65$ years of age & & \\
\hline & 6: $66-75$ years of age & & \\
\hline & 7: 75 and older & & \\
\hline WHITE & 1 if White; 0 otherwise & 0.81 & 0.39 \\
\hline \multirow[t]{4}{*}{ HHSIZE } & 1: $1-2$ household members & 1.49 & 0.7 \\
\hline & 2: 3-4 household members & & \\
\hline & 3: 5-6 household members & & \\
\hline & 4: 7 or more household members & & \\
\hline RETIRED & 1 if Retired; 0 otherwise & 0.75 & 0.44 \\
\hline FT EMPLOYED & 1 if employed full time; 0 otherwise & 0.59 & 0.49 \\
\hline RESIDE NORTH & 1 if household in northern Nevada; 0 otherwise & 0.42 & 0.41 \\
\hline CHEAPTALK & 1 if received cheap talk treatment; 0 otherwise & 0.22 & 0.42 \\
\hline AUCTION & 1 if received auction treatment; 0 otherwise & 0.26 & 0.44 \\
\hline ВОTH & 1 if received cheap talk + auction treatment; 0 otherwise & 0.22 & 0.41 \\
\hline
\end{tabular}

consumer shift in demand towards credence attributes, appearance attributes still play a key role in providing consumers with perceived quality cues. This is a valuable result for producers considering direct marketing who may not have as much experience producing a consistent finished product: not only will the appearance of a meat product affect a consumer's purchase decision; for some products it may also be a deciding factor in whether or not they are willing to pay a premium. 
Although product experience attributes such as taste, flavor, and freshness were assigned the highest average preference ratings by respondents, "EXPERIENCE" yielded a significant effect only on willingness to purchase the differentiated ground beef (5.6 percent), and had no effect on WTP a premium for any product. This may be an indication that taste and flavor are less important to consumers when it comes to purchasing meat products than credence attributes such as feed type and origin, although both attributes have been found to affect taste and flavor.

"MARKETING" attributes had a negative and significant effect on willingness to purchase the differentiated leg of lamb (6.7 percent), which is not unexpected as the components of this factor were related to price and packaging. It is expected that consumers who place an emphasis on these aspects will be less inclined to purchase a potentially pricier product, and leg of lamb is not widely consumed in the U.S. The result for "SPECIALTYMEAT" (purchasing meat primarily from a specialty meat store) was significant only for New York steak, the most expensive cut of meat included in the survey, and increased the probability of willingness to purchase locally grown, grass-fed New York steak by10.9 percent and WTP a premium by 13.7 percent. Purchasing meats from a natural foods store ("NATURALSTORES") had no significant effects in either stage. Taken together, these results tend to indicate that meat purchasing outlets do matter, but perhaps only for certain cuts.

Annual consumer income ("INCOME") had a positive and significant effect on willingness to purchase all differentiated meat types except pork chops, with the marginal effect ranging from 5.1 percent to 7.8 percent for each US $\$ 15,000$ increase in household income. Income remained positive and significant for WTP a premium for both New York steak and ground beef.

"EDUCATION" level was negative and significant for ground beef and leg of lamb for consumer willingness to purchase ( 4.5 percent and 5.5 percent, respectively), but had no effect on consumer WTP a premium. "AGE” was negative and significant for New York steak and ground beef at both stages (negative effect of 4.7 percent to 7.8 percent for an additional 10 years of age), indicating that younger adults were more willing to purchase and pay premiums for differentiated beef products. This result is consistent with previous studies on consumer preferences for grass-fed beef (Umberger et al., 2009), which demonstrate the reluctance of older adults to incorporate new foods into their diet (Pollak, 1970).

"WHITE" had positive and significant effects on consumer WTP a premium for the differentiated steak, lamb, and pork products, but had no effect on consumer willingness to purchase any of the products, which may be related the lack of ethnic diversity in the sample (81 percent of respondents identified themselves as White). The presence of children in the household ("KIDS") had a positive and significant effect on consumer willingness to purchase the differentiated leg of lamb and pork chop products, with marginal effects of 32 percent and 21 percent, respectively, and WTP a premium for the lamb product. This is consistent with previous literature, which finds that the presence of children in the household leads to increased consumer WTP for differentiated products, such as organic and local foods (Batte, Hooker, Haab, \& Beaverson, 2006; Yue \& Tong, 2009).

Household size had a significant negative effect for pork chops (12.6 percent) in the first stage and leg of lamb at both stages, indicating that two additional household members would decrease the probability of purchasing and paying a premium for the state-labeled, grass-fed lamb by 23.9 percent and 28.8 percent, respectively. Xue et al. (2010) had a similar result for grass-fed beef, which was not the case here. This outcome is likely related to the fact that having children in the household was a discrete $0 / 1$ variable, only capturing whether or not the respondent had children in the household as opposed to the number of children. Small families with children may be more willing and able to purchase and pay a premium for differentiated products while larger families with or without children may be constrained.

The survey treatment "BOTH" that incorporated both the cheap talk and the auction script, as well as the treatment with the cheap talk script only, "CHEAPTALK," had a negative and 
significant effect on willingness to purchase differentiated ground beef (17.4 percent and 17.7 percent), but no effects on consumer WTP a premium across meat types. The "AUCTION"only script increased the probability of WTP a premium for ground beef by 12.3 percent and for lamb decreased the probability of purchase by 14.6 percent. These results demonstrate a lack of uniformity in the effects of these measures to reduce hypothetical bias.

\section{WTP Estimation Results}

Mean WTP for each differentiated meat product is given in table 3 for the entire sample, as well as for those respondents only WTP a premium for the product. For New York steak, mean WTP was US $\$ 7.96 /$ lb., or a premium of 33 percent relative to the offered base price of US $\$ 6.00 / \mathrm{lb}$. Sixty-five percent of the respondents were willing to pay more than US $\$ 6.00$ per pound for the New York steak, and their WTP on average was US $\$ 8.38 / \mathrm{lb}$., or a 40 percent premium over the base price. For differentiated ground beef, average WTP over all respondents was estimated as US $\$ 2.42$, a 21 percent premium over the base price of US $\$ 2.00 / \mathrm{lb}$. and a considerable premium for an inferior meat cut. The magnitude of this premium may be related to the lower starting value, as was suspected by Loureiro and Umberger (2003) when comparing WTP premium amounts for COOL-labeled hamburger and steak. In total, 73 percent of respondents were willing to pay a premium for the ground beef, while 85 percent were willing to pay at least the base price of US $\$ 2.00 / \mathrm{lb}$. Pork chops, the most widely consumed cut of pork, had a mean WTP of US\$3.42, a 14 percent premium over the base price of US $\$ 3.00 / \mathrm{lb}$. Seventy percent of respondents were willing to pay a premium over the base price.

While the average WTP for leg of lamb over all respondents was US $\$ 4.81$, a 4 percent discount from the base price, WTP among those respondents who were willing to pay a premium was US $\$ 5.54$, a premium of 11 percent. Fifty-two percent of respondents were willing to pay a premium for the grass-fed lamb product, while 61 percent were willing to pay at least the base price. The relatively lower percentages of persons willing to pay at least the baseline amount may be reflecting preferences for lamb meat, which is not consumed as widely in the U.S. as in other countries.

\section{Discussion and Conclusions}

Overall, the study results indicate a definite market for state origin-labeled differentiated pork and lamb products, especially among higher income, married Whites with one or two children. Results show price premiums ranging from 11 to 15 percent for local lamb and pork products (and 22 to 40 percent for local grass-fed beef products). However, the perceived importance of credence characteristics (such as production methods, labels, etc.) had little impact on purchase propensity for pork and lamb products in our sample. Credence characteristics did have positive and significant effect for the differentiated New York steak and ground beef products. This may be an indication that consumers are more influenced or aware of production protocols in beef products, and perhaps less aware or less concerned with conventional production methods for pork and lamb. For all meats, appearance attributes had a positive and significant effect on willingness to purchase the differentiated product and W'TP for the pork and steak product. This confirms the overall importance of the quality cues consumers receive from the products' visual appearance. Marketing and experience attributes had little impact on either willingness to purchase or WTP, indicating that appearance or credence attributes may be more

Table 3. WTP Estimates for "All" Respondents and Those Willing to Pay a "Premium" (All US\$)

\begin{tabular}{lcccccccc}
\hline Product & \multicolumn{2}{c}{ NY Steak } & \multicolumn{2}{c}{ Ground Beef } & \multicolumn{2}{c}{ Pork Chops } & \multicolumn{2}{c}{ Leg of Lamb } \\
\hline Consumer Sample & All & Premium & All & Premium & All & Premium & All & Premium \\
\hline Product B Mean WTP (\$/lb) & $\$ 7.96$ & $\$ 8.38$ & $\$ 2.42$ & $\$ 2.43$ & $\$ 3.42$ & $\$ 3.46$ & $\$ 4.81$ & $\$ 5.54$ \\
Product A Price (\$/lb) & $\$ 6.00$ & $\$ 6.00$ & $\$ 2.00$ & $\$ 2.00$ & $\$ 3.00$ & $\$ 3.00$ & $\$ 5.00$ & $\$ 5.00$ \\
Discount/Premium (\%) & $33 \%$ & $40 \%$ & $21 \%$ & $22 \%$ & $14 \%$ & $15 \%$ & $-4 \%$ & $11 \%$ \\
\hline
\end{tabular}


important than taste or flavor when making differentiated meat purchases.

Our results show that demographics continue to play a role in consumer preferences for differentiated products. Demographic effects were similar in both stages of the analysis, with a couple of exceptions. The most notable was ethnicity, which was significant only in the WTP a premium model. Demographic effects were more significant for the lamb product, while younger adults and higherincome effects were more prevalent for the two beef products. These results show that targeting specific consumers may be especially important for uncommon products, such as lamb, where consumers have less consumption history. Also, providing information on the health benefits of specialized production methods (natural, organic, grass-fed) may appeal to the growing senior population in the United States.

The WTP estimates differed across the meat products under examination. While mean WTP over all respondents represented a significant premium for the differentiated steak, ground beef, and pork chops, the entire sample was willing to accept a slight discount for the differentiated leg of lamb product. As leg of lamb is already a higherpriced product, consumers may not find as much additional value in a differentiated product. However, at least two-thirds of the respondents were willing to pay the prevailing conventional product price for the differentiated lamb product.

Finally, the effect of survey design on measuring willingness to purchase and WTP is noted. The auction script had a significant negative marginal effect on willingness to purchase lamb, and the "BOTH" treatment (both the auction script and the cheap talk script) had a significant negative effect on ground beef, which was the expected result. By contrast, the auction script had a significant positive effect on WTP a premium for ground beef. Hence, the effects of the cheap talk, auction, and both cheap talk and auction treatments were not uniform across respondents. However, there were several other survey design features present, including the prices respondents received, as well as the order in which both prices and products were presented. It is possible that including only the script treatments, as we have done in this study, does not capture the full effects of the survey design.

This study sheds light on consumer preferences for multiple state origin-labeled differentiated meat products in the western United States. However, due to nonhomogeneous attitudes and knowledge of alternative livestock production methods, as well as differences in ethnic background, consumer preferences will likely differ across regions. Further research clarifying differences across regions and through time would provide more specific information on the potential risks and returns to livestock producers involved in producing and marketing differentiated meat products. Although consumer perceptions of product experience attributes, such as taste and flavor, were not significant in this study, the inclusion of sensory analysis in future studies to link actual consumption experience with WTP estimates may provide additional validity to these results.

\section{Acknowledgments}

This research was supported by the Utah Agricultural Experiment Station, Utah State University, and approved as journal paper number 8380, as well as the Nevada Agricultural Experiment Station and USDA Rural Development. The author would like to thank Margaret Cowee, Wuyang Hu, and Steven Lewis for their assistance, as well as three anonymous reviewers for their helpful suggestions.

\section{References}

Abidoye, B. O., Bulut, H., Lawrence, J. D., Mennecke, B., \& Townsend, A. M. (2011). U.S. consumers' valuation of quality attributes in beef products. Journal of Agricultural and Applied Economics, 43(1), 1-12. http://purl.umn.edu/100645

Acevedo, N., Lawrence, J. D., \& Smith, M. (2006). Organic, natural and grass-fed beef: Profitability and constraints to production in the Midwestern U.S. Ames, Iowa: Iowa State University. Retrieved from http://www.tnbeefcattleinitiative.org/ pdf/ISUOrganicNaturalGrassFedBeef2006.pdf

Bailey, D., Bosworth, R. C., \& Curtis, K. (2012). Utah shopper awareness of and willingness to pay for Utah's Own food products: Phase I report. Logan, Utah: Utah State University Agricultural Experiment Station. 
Batte, M. T., Hooker, N. H., Beaverson, J., \& Haab, T. C. (2006). Putting their money where their mouths are: Consumer willingness to pay for multiingredient, processed organic food products. Food Policy, 32(2), 145-159. http://dx.doi.org/10.1016/j.foodpol.2006.05.003

Burnett, P., Kuethe, T. H., \& Price, C. (2011). Consumer preference for locally grown produce: An analysis of willingness-to-pay and geographic scale. Journal of Agriculture, Food Systems, and Community Development, 2(1), 269-278. http://dx.doi.org/10.5304/jafscd.2011.021.013

Chang, K.-L., Xu, P., Warmann, J., Lone, T., Munzimi, Z.-S., \& Opoku, E. (2013). Consumer characteristics and willingness to pay for locally produced product: A case study of rib-eye steaks in the northern Great Plains. Journal of Agriculture, Food Systems, and Community Development, 4(1), 99-121. http://dx.doi.org/10.5304/jafscd.2013.041.003

Conner, D. S., \& Oppenheim, D. (2008). Demand for pasture-raised livestock products in Michigan: Results of consumer surveys and experimental auctions. Journal of Food Distribution Research, 39(1), 45-50. http://purl.umn.edu/55603

Curtis, K. R., \& Cowee, M. W. (2011). Buying local: Diverging consumer motivations and concerns. Journal of Agribusiness, 29(1), 1-22. Available at http://www.caes.uga.edu/departments/agecon/ publications/index.html

Curtis, K. R., Cowee, M. W., Velcherean, M., \& Gatzke, H. (2010). Farmers market consumers: Is local or organic important? Journal of Food Distribution Research, 41(1), 20-24. http://purl.umn.edu/162167

Dillman, D. A. (2000). Mail and internet surveys: The tailored design method (2nd Ed.). New York: John Wiley \& Sons.

Duckett, S. K., Wagner, D. G., Yates, L. D., Dolezal, H. G., \& May, S. G. (1993). Effects of time on feed on beef nutrient composition. Journal of Animal Science, 71(8), 2079-2088.

http://www.journalofanimalscience.org/

Evans, J. R., D’ Souza, G. E., Collins, A., Brown, C., \& Sperow, M. (2011). Determining consumer perceptions of and willingness to pay for Appalachian grass-fed beef: An experimental economics approach. Agricultural and Resource Economics Review, 40(2), 233-250.
Feuz, D. M., Umberger, W. J., Calkins, C. R., \& Sitz, B. (2004). U.S. consumers' willingness to pay for flavor and tenderness in steaks as determined with an experimental auction. Journal of Agricultural and Resource Economics, 29(3), 501-516. http://www.waeaonline.org/publications/jare

Gracia, A., \& de Magistris, T. (2008). The demand for organic foods in the South of Italy: A discrete choice model. Food Policy, 33(5), 386-396. http://dx.doi.org/10.1016/i.foodpol.2007.12.002

Grannis, J., \& Thilmany, D. (2000, June). Marketing opportunities for natural pork products in the Intermountain West (Colorado State Cooperative Extension Agricultural Marketing Report No. AMR 00-01). Fort Collins, Colorado: Department of Agricultural and Resource Economics. Retrieved from http://dare.colostate.edu/pubs

$\mathrm{Hu}, \mathrm{W}$. (2006). Use of spike models in measuring consumers' willingness to pay for non-GM oil. Journal of Agricultural and Applied Economics, 38(3), 525-538. http://purl.umn.edu/43786

Hu, W., Zhong, F., \& Ding, Y. (2006). Actual media reports on GM foods and Chinese consumers' willingness to pay for GM soybean oil. Journal of Agricultural and Resource Economics, 31(2), 376-390. http://www.waeaonline.org/publications/jare

Lancaster, K. J. (1966). A new approach to consumer theory. Journal of Political Economy, 74(2), 132-157. http://dx.doi.org/10.1086/259131

Loureiro, M. L., \& Umberger, W. J. (2003). Estimating consumer willingness to pay for country-of-origin labeling. Journal of Agricultural and Resource Economics, 28(2), 287-301. http://www.waeaonline.org/publications/jare

Loureiro, M. L., \& Umberger, W. J. (2005). Assessing consumer preferences for country-of-origin labeling. Journal of Agricultural and Applied Economics, 37(1), 49-63. http://purl.umn.edu/43712

Lusk, J. L., Fields, D., \& Prevatt, W. (2008). An incentive compatible conjoint ranking mechanism. American Journal of Agricultural Economics, 90(2), 487498. http://dx.doi.org/10.1111/j.1467-8276.2007. 01119.x

Lusk, J. L., \& Parker, N. (2009). Consumer preferences for amount and type of fat in ground beef. Journal of Agricultural and Applied Economics, 41(1), 75-90. http://purl.umn.edu/48763 
McCluskey, J. J., \& Loureiro, M. L. (2003). Consumer preferences and willingness to pay for food labeling: A discussion of empirical studies. Journal of Food Distribution Research, 34(3), 95-102. http://purl.umn.edu/27051

McCluskey, J. J., Wahl, T. I., Li, Q., \& Wandschneider, P. R. (2005). U.S. grass-fed beef: Marketing health benefits. Journal of Food Distribution Research, 36(3), 1-8. http://purl.umn.edu/27758

Mennecke, B. E., Townsend, A. M., Hayes, D. J., \& Lonergan, S. M. (2007). A study of the factors that influence consumer attitudes toward beef products using the conjoint market analysis tool. Journal of Animal Science, 85(10), 2639-2659. http://dx.doi.org/10.2527/jas.2006-495

Nganje, W. E., Hughner, R. S., \& Lee, N. E. (2011). State-branded programs and consumer preference for locally grown produce. Agricultural and Resource Economics Review, 40(1), 20-32. http://purl.umn.edu/107472

Onken, K. A., \& Bernard, J. C. (2010). Catching the "local" bug: A look at state agricultural marketing programs. Choices: The Magazine of Food, Farm and Resource Issues, 25(1). Retrieved from http://farmdoc.illinois.edu/policy/choices/20101/ 2010106/2010106.html

Pimentel, D., Oltenacu, P. A., Nesheim, M. C., Krummel, J., Allen, M. S., \& Chick, S. (1980). The potential for grass-fed livestock: Resource constraints. Science, 207(4433), 843-848. http://dx.doi.org/10.1126/science.207.4433.843

Pollak, R. A. (1970). Habit formation and dynamic demand functions. Journal of Political Economy, 78(4), 745-763. http://dx.doi.org/10.1086/259667

Resano, H., Sanjuan, A. I., \& Albisu, L. M. (2009, September). Evidence on the value of $\mathrm{EU}$ quality certification schemes. The case of dry-cured ham in Spain. Paper presented at the $113^{\text {th }}$ EAAE seminar, Chania, Crete, Greece. http://purl.umn.edu/58117
Silva, A., Nayga, Jr., R. M., Campbell, B. L., \& Park, J. L. (2011). Revisiting cheap talk with new evidence from a field experiment. Journal of Agricultural and Resource Economics, 36(2), 280-291. http://www.waeaonline.org/publications/jare

Umberger, W. J., Boxall, P. C., \& Lacy, R. C. (2009). Role of credence and health information in determining US consumers' willingness-to-pay for grass-finished beef. Australian Journal of Agricultural and Resource Economics, 53(4), 603-623.

http://dx.doi.org/10.1111/j.14678489.2009.00466.x

Umberger, W. J., Feuz, D. M., Calkins, C. R., \& Killinger-Mann, K. (2002). U.S. consumer preference and willingness-to-pay for domestic corn-fed beef versus international grass-fed beef measured through an experimental auction. Agribusiness, 18(4), 491-504. http://dx.doi.org/10.1002/agr.10034

Umberger, W. J., Feuz, D. M., Calkins, C. R., \& Sitz, B. M. (2003). Country-of-origin labeling of beef products: U.S. consumers' perceptions. Journal of Food Distribution Research, 34(3), 103-116. http://purl.umn.edu/27050

U.S. Census Bureau. (n.d.). State \& county QuickFacts: Nevada. Retrieved 2010 from http://quickfacts. census.gov/qfd/states/32000.html

Xue, H., Mainville, D., You, W., \& Nayga Jr., R. M. (2010). Consumer preferences and willingness to pay for grass-fed beef: Empirical evidence from instore experiments. Food Quality and Preference, 21(7), 857-866. http://dx.doi.org/10.1016/j.foodqual.2010.05.004

Yue, C., \& Tong, C. (2009). Organic or local? Investigating consumer preference for fresh produce using a choice experiment with real economic incentives. HortScience, 44(2), 366-371. Retrieved from http://hortsci.ashspublications.org/ 


\section{Appendix}

\section{Table A1. Consumer Willingness to Purchase Model Results (Logit)}

\begin{tabular}{|c|c|c|c|c|c|c|c|c|c|c|c|c|}
\hline \multirow[b]{2}{*}{ Variable Name } & \multicolumn{3}{|c|}{ NY Steak } & \multicolumn{3}{|c|}{ Ground Beef } & \multicolumn{3}{|c|}{ Leg of Lamb } & \multicolumn{3}{|c|}{ Pork Chops } \\
\hline & Coefficient & $\begin{array}{l}\text { Standard } \\
\text { Error }\end{array}$ & $\begin{array}{c}\text { Marginal } \\
\text { Effect }\end{array}$ & Coefficient & $\begin{array}{c}\text { Standard } \\
\text { Error }\end{array}$ & $\begin{array}{c}\text { Marginal } \\
\text { Effect }\end{array}$ & Coefficient & $\begin{array}{c}\text { Standard } \\
\text { Error }\end{array}$ & $\begin{array}{c}\text { Marginal } \\
\text { Effect }\end{array}$ & Coefficient & $\begin{array}{c}\text { Standard } \\
\text { Error }\end{array}$ & $\begin{array}{c}\text { Marginal } \\
\text { Effect }\end{array}$ \\
\hline CREDENCE & $0.521 * * *$ & 0.145 & $0.122 * * *$ & $0.765 * * *$ & 0.155 & $0.177 * * *$ & 0.166 & 0.150 & 0.041 & 0.044 & 0.146 & 0.011 \\
\hline EXPERIENCE & 0.202 & 0.133 & 0.047 & $0.241 *$ & 0.134 & $0.056 *$ & -0.134 & 0.143 & -0.033 & 0.089 & 0.136 & 0.022 \\
\hline APPEARANCE & $0.280 * *$ & 0.137 & $0.065 * *$ & $0.286 * *$ & 0.141 & $0.066 * *$ & $0.358 * *$ & 0.150 & $0.089 * *$ & $0.347 * *$ & 0.144 & $0.085 * *$ \\
\hline MARKETING & 0.060 & 0.145 & 0.014 & 0.028 & 0.150 & 0.006 & $-0.271 *$ & 0.142 & $-0.067 *$ & -0.148 & 0.140 & -0.036 \\
\hline NATURALSTORES & 0.353 & 0.280 & 0.082 & -0.157 & 0.285 & -0.036 & -0.079 & 0.249 & -0.020 & -0.029 & 0.245 & -0.007 \\
\hline SPECIALTYMEAT & $0.467 *$ & 0.245 & $0.109 *$ & 0.314 & 0.249 & 0.072 & -0.048 & 0.268 & -0.012 & 0.048 & 0.267 & 0.012 \\
\hline EDUCATION & -0.077 & 0.113 & -0.018 & $-0.200 *$ & 0.116 & $-0.046 *$ & $-0.221 * *$ & 0.113 & $-0.055 * *$ & -0.138 & 0.112 & -0.034 \\
\hline INCOME & $0.312 * *$ & 0.109 & $0.073 * * *$ & $0.339 * * *$ & 0.111 & $0.078 * * *$ & $0.206 * *$ & 0.099 & $0.051 * *$ & 0.039 & 0.098 & 0.010 \\
\hline MARRIED & -0.062 & 0.306 & -0.015 & 0.098 & 0.316 & 0.023 & 0.095 & 0.318 & 0.023 & $0.653 * *$ & 0.310 & $0.160 * *$ \\
\hline KIDS & 0.335 & 0.485 & -0.079 & -0.081 & 0.508 & -0.019 & $1.321 * *$ & 0.522 & $0.319 * * *$ & $0.891 *$ & 0.495 & $0.209 *$ \\
\hline AGE & $-0.257 * *$ & 0.126 & $-0.060 * *$ & $-0.224 *$ & 0.129 & $-0.052 *$ & 0.009 & 0.119 & 0.002 & -0.046 & 0.116 & -0.011 \\
\hline WHITE & 0.470 & 0.337 & 0.113 & 0.196 & 0.344 & 0.046 & 0.353 & 0.389 & 0.086 & 0.360 & 0.371 & 0.089 \\
\hline HHSIZE & -0.309 & 0.301 & -0.072 & -0.185 & 0.315 & -0.043 & $-0.968 * * *$ & 0.342 & $-0.239 * * *$ & $-0.513^{*}$ & 0.316 & $-0.126 *$ \\
\hline CHEAPTALK & -0.040 & 0.384 & -0.009 & $-0.723^{*}$ & 0.397 & $-0.174 *$ & -0.173 & 0.383 & -0.042 & -0.385 & 0.378 & -0.095 \\
\hline ВОTH & 0.373 & 0.361 & 0.085 & $-0.742 * *$ & 0.366 & $-0.177 * *$ & -0.531 & 0.426 & -0.127 & 0.259 & 0.428 & 0.063 \\
\hline CONSTANT & -0.909 & 1.342 & & 0.949 & 1.375 & & 1.244 & 1.365 & & 0.674 & 1.351 & \\
\hline Observations & 282 & & & 282 & & & 259 & & & 259 & & \\
\hline Pseudo R2 & 0.1227 & & & 0.1633 & & & 0.1048 & & & 0.0799 & & \\
\hline Log likelihood & -165.46 & & & -157.42 & & & -159.63 & & & -163.25 & & \\
\hline
\end{tabular}

$* * *, * *, *$ : Statistically significant at the $1 \%, 5 \%$, and $10 \%$ confidence levels, respectively. 
Table A2. Consumer WTP Premium Model Results (Logit)

\begin{tabular}{|c|c|c|c|c|c|c|c|c|c|c|c|c|}
\hline \multirow[b]{2}{*}{ Variable Name } & \multicolumn{3}{|c|}{ NY Steak } & \multicolumn{3}{|c|}{ Ground Beef } & \multicolumn{3}{|c|}{ Leg of Lamb } & \multicolumn{3}{|c|}{ Pork Chops } \\
\hline & Coefficient & $\begin{array}{l}\text { Standard } \\
\text { Error }\end{array}$ & $\begin{array}{c}\text { Marginal } \\
\text { Effect }\end{array}$ & Coefficient & $\begin{array}{l}\text { Standard } \\
\text { Error }\end{array}$ & $\begin{array}{c}\text { Marginal } \\
\text { Effect }\end{array}$ & Coefficient & $\begin{array}{l}\text { Standard } \\
\text { Error }\end{array}$ & $\begin{array}{c}\text { Marginal } \\
\text { Effect }\end{array}$ & Coefficient & $\begin{array}{l}\text { Standard } \\
\text { Error }\end{array}$ & $\begin{array}{c}\text { Marginal } \\
\text { Effect }\end{array}$ \\
\hline CREDENCE & $0.384 * * *$ & 0.144 & $0.085^{* * *}$ & $0.392 * * *$ & 0.150 & $0.072 * * *$ & -0.021 & 0.144 & -0.005 & 0.075 & 0.156 & 0.015 \\
\hline EXPERIENCE & 0.050 & 0.132 & 0.011 & 0.143 & 0.134 & 0.026 & -0.008 & 0.138 & -0.002 & 0.087 & 0.144 & 0.017 \\
\hline APPEARANCE & $0.277 * *$ & 0.140 & $0.061 * *$ & 0.223 & 0.147 & 0.041 & 0.215 & 0.141 & 0.054 & $0.398 * *$ & 0.157 & $0.079 * * *$ \\
\hline MARKETING & -0.124 & 0.149 & -0.027 & 0.099 & 0.156 & 0.018 & -0.027 & 0.137 & -0.007 & -0.152 & 0.158 & -0.030 \\
\hline NATURALSTORES & 0.271 & 0.281 & 0.060 & -0.300 & 0.295 & -0.055 & 0.161 & 0.242 & 0.040 & -0.260 & 0.270 & -0.052 \\
\hline SPECIALTYMEAT & $0.621 * *$ & 0.246 & $0.137 * *$ & 0.344 & 0.260 & 0.063 & 0.102 & 0.261 & 0.026 & 0.289 & 0.298 & 0.058 \\
\hline EDUCATION & 0.018 & 0.114 & 0.004 & -0.066 & 0.122 & -0.012 & -0.106 & 0.110 & -0.026 & -0.058 & 0.122 & -0.012 \\
\hline INCOME & $0.189 *$ & 0.106 & $0.042 *$ & $0.301 * * *$ & 0.116 & $0.055 * * *$ & 0.130 & 0.097 & 0.033 & 0.036 & 0.106 & 0.007 \\
\hline MARRIED & 0.141 & 0.304 & 0.031 & -0.189 & 0.328 & -0.035 & -0.174 & 0.310 & -0.043 & 0.107 & 0.335 & 0.021 \\
\hline KIDS & -0.012 & 0.504 & -0.003 & 0.170 & 0.543 & 0.031 & $1.095 * *$ & 0.508 & $0.262 * *$ & 0.265 & 0.526 & 0.052 \\
\hline AGE & $-0.353 * * *$ & 0.131 & $-0.078 * * *$ & $-0.254 *$ & 0.136 & $-0.047 *$ & -0.040 & 0.115 & -0.010 & -0.067 & 0.127 & -0.013 \\
\hline WHITE & $0.788 * *$ & 0.336 & $0.184 * *$ & 0.455 & 0.350 & 0.089 & $0.877 * *$ & 0.380 & $0.214 * *$ & $1.273 * * *$ & 0.383 & $0.288 * * *$ \\
\hline HHSIZE & -0.349 & 0.310 & -0.077 & -0.315 & 0.336 & -0.058 & $-1.152 * * *$ & 0.339 & $-0.288 * * *$ & -0.284 & 0.331 & -0.057 \\
\hline CHEAPTALK & -0.038 & 0.396 & -0.008 & -0.203 & 0.403 & -0.039 & 0.289 & 0.378 & 0.072 & -0.035 & 0.410 & -0.007 \\
\hline ВОТН & -0.197 & 0.362 & -0.044 & -0.347 & 0.374 & -0.066 & 0.093 & 0.412 & 0.023 & 0.574 & 0.483 & 0.105 \\
\hline CONSTANT & -0.728 & 1.361 & & 1.465 & 1.430 & & 0.244 & 1.335 & & 0.205 & 1.457 & \\
\hline Observations & 282 & & & 282 & & & 259 & & & 259 & & \\
\hline Pseudo R2 & 0.1126 & & & 0.0954 & & & 0.0716 & & & 0.0931 & & \\
\hline Log likelihood & -162.19 & & & -148.66 & & & -166.44 & & & -142.94 & & \\
\hline
\end{tabular}

